\title{
MAPEAMENTO DA SUSCETIBILIDADE A DESLIZAMENTOS USANDO TÉCNICAS DE ESTATÍSTICA BIVARIADA E SISTEMA DE INFORMAÇÕES GEOGRÁFICAS NA REGIÃO NORDESTE DO RIO GRANDE DO SUL
}

\section{MAPPING OF LANDSLIDE SUSCEPTIBILITY USING BIVARIATE STATISTICAL TECHNIQUES AND GEOGRAPHIC INFORMATION SYSTEM IN THE NORTHEASTERN OF RIO GRANDE DO SUL STATE}

Roberto Nunes Vanacôr

Fundação de Ciência e Tecnologia (CIENTEC) - Rua Washington Luiz, 675/P.8. - Porto Alegre - RS. - CEP: 90010-460 e-mail: roberto-vanacor@cientec.rs.gov.br

Silvia Beatriz Alves Rolim Av. Bento Gonçalves, 9500 - Campus do Vale - Agronomia - Caixa Postal: 15044 - CEP 91501-970 - Porto Alegre - RS -

\begin{abstract}
Resumo
Este trabalho apresenta um método para mapeamento de suscetibilidade a deslizamentos na região nordeste do Rio Grande Sul, Brasil. O método é baseado em duas principais linhas de pesquisa: 1) a seleção e análise dos fatores condicionantes de deslizamentos e 2) o mapeamento de susceptibilidade com uso de um Sistema de Informações Geográficas (SIG), sensoriamento remoto e estatística bivariada. Durante a pesquisa foram testados estatisticamente parâmetros topográficos, geológicogeotécnicos e antrópicos gerados a partir de imagens ASTER, fotografias aéreas e mapas temáticos. Para determinar o peso dos fatores e diminuir a subjetividade no processo de decisão, foi avaliada a contribuição relativa de cada um deles com uso da técnica Analytical Hierarchy Process (AHP), baseada na lógica de comparação pareada. Por fim, através da avaliação por critérios múltiplos, foi definido o peso de cada plano de informação empregando o método de combinação linear ponderada, obtendo como produto o mapa de susceptibilidade da área. A metodologia utilizada se mostrou rápida, de fácil aplicação e relativamente de baixo custo, podendo ser usada por instituições públicas para a previsão de deslizamentos e para auxiliar no gerenciamento do uso do solo.
\end{abstract}

Palavras-chave: Susceptibilidade a deslizamentos, Processo hierárquico analítico, SIG

\begin{abstract}
This paper presents a method for mapping susceptibility to landslides in the northeast region of Rio Grande Sul State, Brazil. The method is based on two main lines of research: 1) the selection and analysis of conditioning factors of landslides and 2) the susceptibility mapping using a Geographic Information System (GIS), remote sensing tools and bivariate statistics. To achieve this goal, the following parameters were statistically tested activities from ASTER images, aerial photographs and thematic maps: topography, geology and geotechnical information and human. To determine the weight of factors and reduce
\end{abstract}


the subjectivity in decision-making, it was assessed the relative contribution of each technique with the use of Analytical Hierarchy Process (AHP), based on the logic of paired comparison. Finally, through evaluation of multiple criteria, it was defined the weight of each information layer using the method of weighted linear combination, obtained as the product of susceptibility map of the area. The methodology was quick, easy application and relatively low cost and can be used by public institutions for the prediction of landslides and to assist in the management of land use.

Keywords: Susceptibility to landslides, Analytical hierarchy process, GIS

\section{Introdução}

Deslizamentos são desastres naturais que ocorrem quase todos os dias em algum lugar do mundo, resultando muitas vezes em prejuízos econômicos significativos e em perdas de vidas. Na região Nordeste do Rio Grande do Sul, deslizamentos ocorridos em dezembro de 2000, após chuvas intensas e concentradas, geraram perdas e danos a pessoas e propriedades.

A literatura científica mostra um número crescente de pesquisas realizadas com o intuito de reduzir os efeitos de deslizamentos, principalmente em áreas com habitações instaladas em regiões serranas, que frequentemente são afetadas por tais processos. Diversos autores têm proposto novas metodologias, fazendo uso de modelos qualitativos e quantitativos, diretos e indiretos, para a previsão de áreas propensas a deslizamentos.

O mapeamento de suscetibilidade é o primeiro passo no sentido de mitigar efetivamente áreas propensas a deslizamentos e minimizar as consequências negativas destes eventos na sociedade.

Uma das dificuldades encontradas neste tipo de estudo é analisar a grande quantidade de informações, devido à complexidade dos processos envolvidos. Para facilitar os procedimentos de análise foram aplicadas técnicas de interpretação de imagens e manipulação de dados através de Sistema de Informações Geográficas (SIG). As informações utilizadas foram obtidas a partir de fotografias aéreas, do Modelo Digital de Terreno (MDT) da área, de imagem do sensor Advanced Spaceborne Thermal Emission and Reflection Radiometer (ASTER) e através de mapas temáticos, gerados com base em diversas fontes.

Este artigo apresenta os principais resultados obtidos na elaboração do mapa de suscetibilidade a deslizamentos, buscando definir os locais mais críticos, auxiliar no planejamento da ocupação das encostas, subsidiar a adoção de medidas preventivas e corretivas em regiões onde já ocorreram deslocamentos de massa e, consequentemente, aumentar a segurança da população civil.

\section{Área de Estudo}

A área de estudo localiza-se na região nordeste do Estado do Rio Grande do Sul, Brasil, entre as coordenadas UTM $460.000 \mathrm{~m}$ e $476.000 \mathrm{~m}$ (E) e $6.744 .000 \mathrm{~m}$ e 6.758 .490 m (N), abrangendo os municípios de São Vendelino e Alto Feliz (Figura 1).

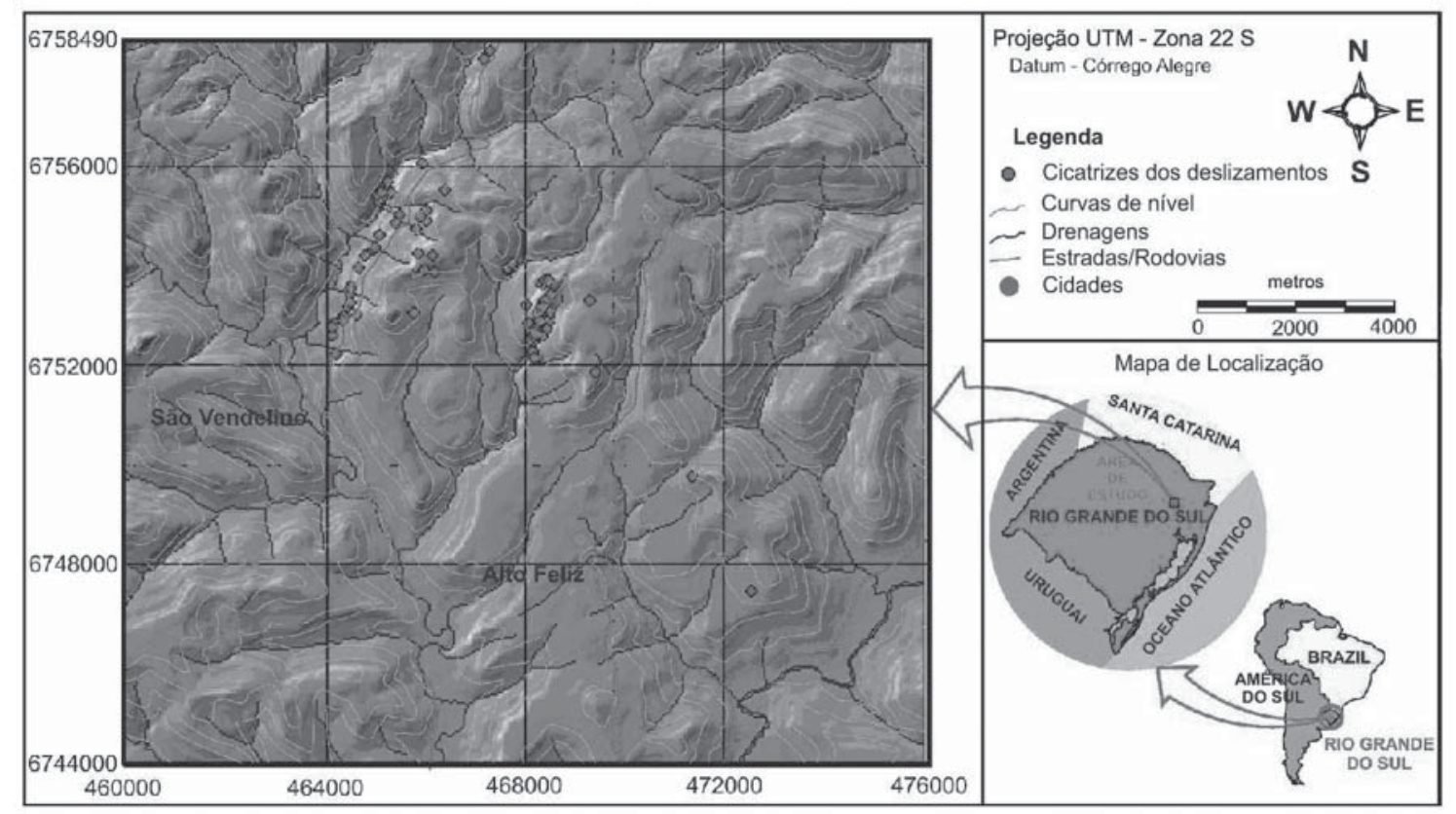

Figura 1 - Mapa da área de estudo e localização das cicatrizes dos deslizamentos 
O relevo da região é fortemente acidentado com altitudes variando entre 20 e 720 metros acima do nível do mar e apresenta uma precipitação pluviométrica bem distribuída ao longo do ano.

Devido aos lineamentos tectônicos locais e do grau de dissecação, a direção das formas de relevo e dos principais cursos d'água são variadas e subordinadas à direção dos fraturamentos. Em consequência do clima úmido atual a região demonstra um intenso trabalho de dissecação do relevo e intemperismo químico, originando um relevo acidentado com vertentes côncavo-convexas, onde as encostas e os patamares se apresentam escalonados, deixando à mostra os diversos níveis de derrames vulcânicos existentes na região.

$\mathrm{Na}$ área de estudo são observadas duas unidades geológicas pertencentes ao Grupo São Bento, a Formação Serra Geral e a Formação Botucatu. A Formação Serra Geral, de maior ocorrência na região, é caracterizada por uma sucessão de derrames basálticos superpostas por derrames ácidos (riolitos), tendo na base os arenitos da Formação Botucatu. Os derrames basálticos apresentam espessuras variadas, normalmente de pequena a moderada, raramente ultrapassando 15 metros, já os derrames ácidos apresentam maiores espessuras que atingem até 60 metros. (Roisenberg e Viero, 2000).

De um modo geral, todo este arcabouço geológico está intemperizado e, devido à declividade do terreno, apresenta camadas de solo pouco desenvolvido. Nas encostas e nas partes de maior declividade, observa-se com frequência a presença de depósitos de colúvios e tálus, enquanto nos patamares podem ser identificados depósitos aluviais incipientes.

Os principais solos da região são a seguir descritos:

Solo superficial - Sua espessura é variável (entre 0,5 e 2 metros). Pode ser formado por um sub-horizonte superior transportado e por um horizonte residual, isto é, resultante do intemperismo e pedogênese mais intensos e, portanto, com uma maior quantidade da fração argilosa, sendo por isso mais coesivos. Normalmente apresenta alguns fragmentos de rocha imersos na matriz de finos.

Solo saprolítico ou solo de alteração de basalto - horizonte de solo resultante da atividade intempérica química sobre a rocha matriz, praticamente não submetido a processo pedogenético. Apresenta nítidos vestígios texturais da rocha matriz. Normalmente são silto-arenosos ou areno-siltosos, com fragmentos de rocha e pouca argila. Possuem espessura bastante variável na área, de 1 a vários metros e apresenta grande heterogeneidade devido a seus aspectos texturais e estruturais.
Solos coluvionares e corpos de tálus - normalmente, estes depósitos estão associados à parte baixa da vertente, com menor declividade, apresentando-se mais espessos. Os corpos de tálus se alojam em anfiteatros com topografia mais suavizada. Os corpos coluvionares de meia encosta normalmente apresentam na área espessuras em torno de 1 a 4 metros e possuem composição argilo-siltoarenosa com presença de fragmentos de rocha. Os corpos de tálus podem atingir espessuras de algumas dezenas de metros, sendo invariavelmente constituídos de uma matriz argilo-silto-arenosa que envolve um número considerável de fragmentos e blocos de rocha centimétricos a decimétricos.

Levando-se em conta os condicionamentos geológicogeotécnicos, geomorfológicos, hidrológicos e climáticos atuantes, a região apresenta um grande potencial para deslizamentos, sendo os fluxos de detritos os mais frequentes durante períodos de chuva intensa.

\section{Características dos Deslizamentos}

Os deslizamentos fazem parte da dinâmica da paisagem e são um dos principais processos geomorfológicos responsáveis pela sua evolução, principalmente em áreas com relevo acidentado e regiões montanhosas. Eles movimentam solo e materiais rochosos ao longo das vertentes em direção às planícies e auxiliam o recuo das encostas e a formação das rampas coluviais em conjunto com os processos erosivos.

De acordo com Cruden (1991) deslizamento (landslide na língua inglesa) denota movimentos de rocha, solo e mistura de solos e rochas, das partes mais elevadas para as partes mais baixas da encosta.

Existem vários sistemas de classificação internacionais e brasileiros para deslizamentos, como os apresentados por Sharpe 1938, Freire 1965, Varnes 1978, Guidicini e Nieble 1984, Hutchinson 1988, IPT 1991, entre outros. Estes sistemas classificatórios são baseados em diversos fatores, que combinam critérios como: mecanismos do movimento, natureza dos materiais envolvidos, velocidade de deformação do movimento, direção e recorrência dos movimentos e geometria da massa movimentada.

Esta pesquisa foi baseada na classificação proposta por Filho e Wolle (1996), mostrada na Tabela 1, onde são descritos de forma sucinta os referidos processos. Dentre as formas genéricas de deslizamentos presentes nesta classificação estão os processos de rastejo, escorregamento, movimento de blocos rochosos e fluxo de detritos sendo estes tipos de deslizamentos os mais frequentes para a dinâmica de ambiente tropical do Brasil. 
Tabela 1 - Principais tipos de deslizamento em regiões tropicais Filho e Wolle (1996).

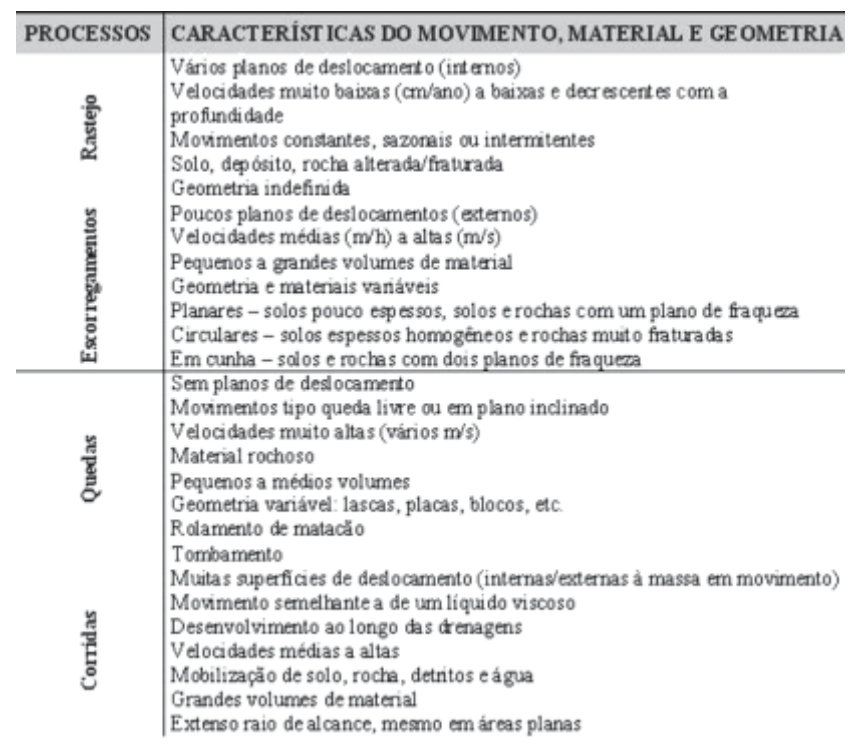

As principais formas de deslizamentos observadas na área de estudo, a partir de trabalhos de campo, fotografias aéreas e imagens de satélite, foram fluxos de detritos, escorregamentos translacionais de taludes infinitos, quedas de blocos e rastejos de colúvios em menor proporção.

Os fluxos de detritos apresentaram alto poder destrutivo, resultando da ocorrência simultânea e da confluência de escorregamentos translacionais e pela presença, nas margens íngremes dos canais, de colúvios rasos que, durante eventos pluviométricos intensos e prolongados, tendem a instabilizar-se. As bordas das unidades vulcânicas ácidas representam a principal quebra de relevo da região, onde o fluxo hidráulico nos canais assume grande energia e velocidade, conduzindo os detritos a jusante. A Figura 2 mostra um fluxo de detritos de grandes dimensões que cruzou a rodovia $\mathrm{RS} / 122$, principal acesso ao município de Caxias do Sul.

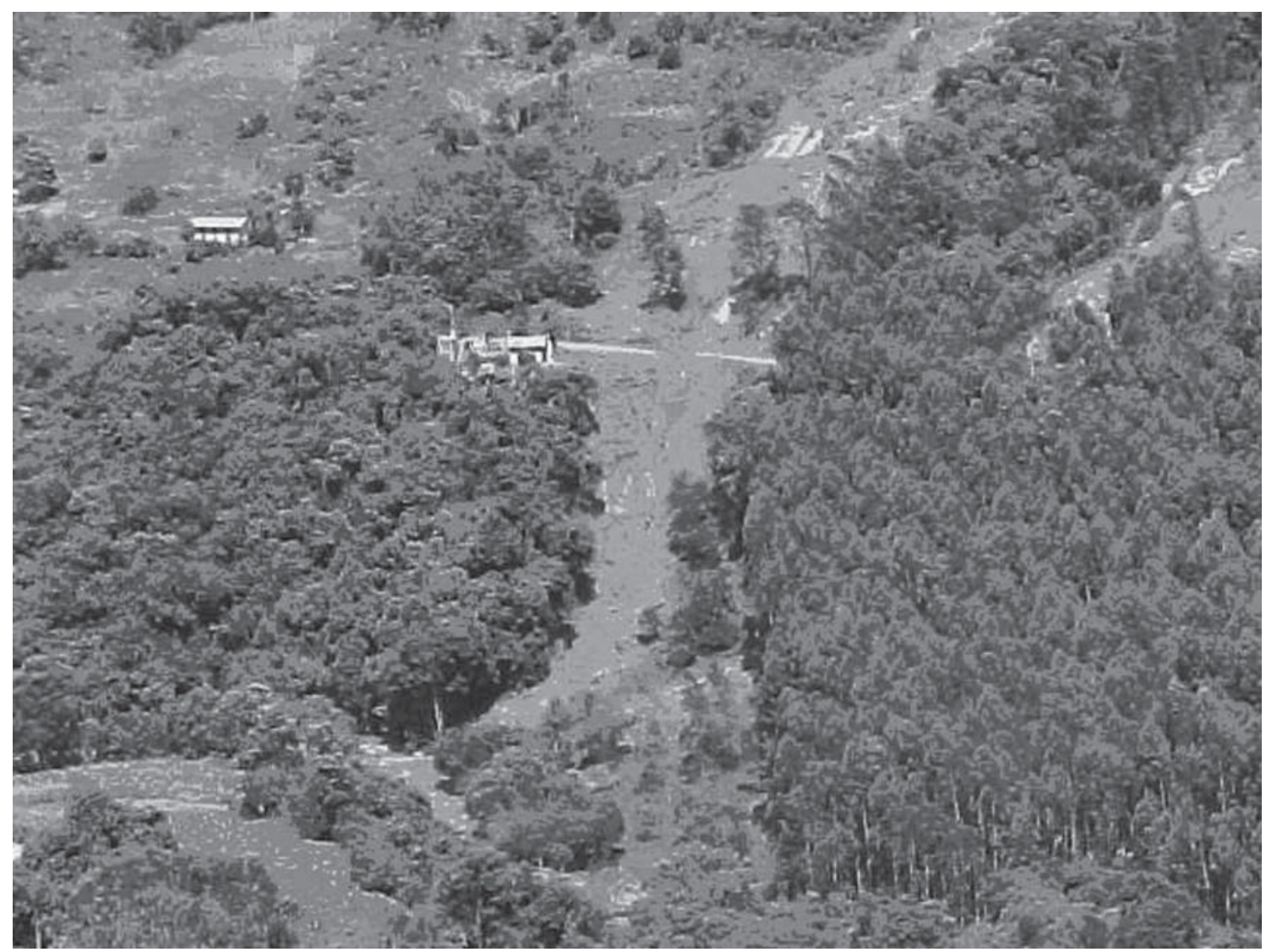

Figura 2 - Deslizamento de encosta de grandes proporções em Alto Feliz, próximo a RS 122. 
Os escorregamentos translacionais ocorreram com frequência, acompanhando descontinuidades mecânicas, alguns deles mobilizando material em direção dos talvegues e canais naturais de drenagem, muitas vezes passando a fluxo de detritos devido às condições favoráveis (canais de drenagem extensos, bacias de contribuição amplas e declividade acentuada).

A ocorrência de queda e desplacamento de blocos são condicionadas pelas descontinuidades das rochas, representadas principalmente por juntas de alívio, com grande persistência e mergulho desfavorável.

\section{Metodologia}

O trabalho utilizou o método estatístico bivariado, descrito por Soeters e Van Westen (1996). Este método é baseado nas análises dos fatores que geraram deslizamentos no passado, determinados estatisticamente, para incorporar a avaliação das incertezas associadas ao mapeamento dos indicadores. Posteriormente são feitas predições para áreas livres de deslizamentos, onde se observam condições similares.

Os métodos estatísticos podem ser divididos em bivariados e multivariados. Ambos fazem uso da frequência ou densidade de deslizamentos por classe para a determinação dos pesos. A principal diferença entre as duas análises está no fato de que a primeira considera o peso de cada classe e de cada parâmetro de análise utilizando técnicas de inferência (Lógica Fuzzy e regras de combinação Bayesiana, por exemplo), enquanto a segunda considera para cada unidade amostral (polígono ou pixel) a presença ou ausência de deslizamento, gerando uma matriz de dados que é exportada e analisada em um pacote estatístico, tais como regressão múltipla, análise discriminante, etc. (Soeters e Van Westen, 1996).

A existência ou previsão de deslizamentos é resultante da conjunção de processos ou fatores condicionantes, e a probabilidade ou suscetibilidade de sua ocorrência pode ser representada pelo resultado da combinação com que cada variável de cada um dos fatores selecionados contribui para a ocorrência do evento. Segundo Guzzetti et al. (1999), suscetibilidade a deslizamentos é definida pela propensão do terreno a produzir ruptura de taludes. Matematicamente, pode ser considerada como a probabilidade de ocorrência espacial de rupturas em encostas com características conhecidas, dada uma série de condições ambientais. A ocorrência destes processos é o resultado da combinação favorável de uma ou mais condicionantes, as quais em geral não são acessíveis à investigação direta. Como alternativa, é possível investigá-la por meio de variáveis que apresentam relação de dependência com estas condicionantes e, consequentemente, relação com a ocorrência do processo.
De acordo com Soeters e Van Westen (1996), a previsão de deslizamentos para áreas livres de tais processos é baseada na suposição de que os eventos ocorridos no passado podem prover informações úteis para predizer futuras ocorrências.

Com base no método estatístico, as abordagens foram desenvolvidas buscando diminuir a subjetividade e visando uma melhor repetitividade nos mapeamentos de áreas susceptíveis. Os métodos estatísticos, segundo Clerici et al. (2006), são mais objetivos, têm maior rigor formal e uma melhor adequação para análises de probabilidade, especialmente em médias escalas.

O método aplicado pode ser resumido em oito principais etapas:

E1- avaliação dos fatores condicionantes;

E2- criação da base cartográfica digital;

E3- análise estatística e espacial;

E4- padronização dos planos de informação;

E5- ponderação dos planos de informação;

E6- avaliação por critérios múltiplos;

E7- definição dos graus de suscetibilidade;

E8- verificação da acurácia.

\section{E1 - Avaliação dos fatores condicionantes}

Várias feições podem atuar como fatores condicionantes dos deslizamentos, determinando a localização espacial e temporal destes movimentos em campo. Muitas destas feições possuem sua origem associada a processos geológicos e geomorfológicos que atuaram no passado e que, em muitos casos, são atuantes no presente (Fernandes e Amaral, 2003).

A erosão dos solos na sua forma mais ampla, embora seja um dos fenômenos naturais mais estudados, ainda é pouco compreendida, principalmente no que se refere a sua previsão, tanto no espaço como no tempo. Tal dificuldade resulta, dentre outras razões, das complexas interações entre os diversos fatores condicionantes, os vários mecanismos de ruptura dos solos, as características de transporte, além das intervenções antrópicas, cada vez mais frequentes. Além disso, as diferentes feições erosivas observadas na natureza encontram-se associadas a processos bem específicos, fato que dificulta ainda mais o desenvolvimento de estudos voltados para a previsão (Selby, 1993; Morgan, 1996, entre outros).

Diversos autores estudam métodos objetivos para caracterizar o papel desempenhado e classificar a importância dos fatores que condicionam os deslizamentos, com o objetivo de auxiliar na definição da influência de cada fator para construir mapas de suscetibilidade (e.g. Donati e Turrini 2002, Fernandes et al. 2001). 
Sabe-se que os deslizamentos são condicionados por complexas relações entre fatores geológicos, englobando as características lito-estruturais e tectônicas, geomorfológicas, climáticas e antrópicas.

Neste estudo buscou-se criar o modelo conceitual ou modelo hipotético da área analisada, que representa a complexidade dos fatores relacionados aos deslizamentos, com base nas informações que possuem relação direta (temporais e espaciais) com estes fatores, bem como nortear o planejamento da implantação de um processo de integração de informações georreferenciadas. Dessa forma, há a necessidade de uso de informações em diferentes níveis, chamados de planos de informação (PIs).

Para a criação do modelo conceitual, foram utilizados fatores ambientais condicionantes dos deslizamentos, envolvendo os agentes e causas, geometria, mecanismos de movimentação e natureza dos materiais mobilizados por estes processos. Cada fator ambiental é caracterizado por uma série de variáveis espaciais, sendo a relação com o evento definida pelo resultado da análise estatística obtida. Os fatores, representados pelos PIs e suas variáveis, são descritos a seguir e foram considerados potencialmente relacionados com o evento, formando o modelo conceitual da área de estudo.

ALTIMETRIA - A espessura do solo está diretamente relacionada à altimetria. Nas áreas mais elevadas, de planalto, encontram-se as rochas vulcânicas ácidas, com superfícies planas a levemente inclinadas, onde são encontrados solos de pequena espessura, causando escorregamentos de pequena magnitude como escoamento laminar, sulcos, ravinas e pequenos escorregamentos. Já nas partes mais altas de encostas as rochas vulcânicas ácidas apresentam características geomorfológicas de patamares escalonados originados pelos derrames. Nesta faixa altimétrica corre uma quebra bastante acentuada do relevo (escarpa) com declividade acentuada e pequena espessura dos solos, provocando escoamento laminar, sulcos, ravinas e pequenos escorregamentos. Localizadamente, ocorrem corridas e quedas (rolamento e tombamento).

$\mathrm{Na}$ área de meia encosta predominam as rochas vulcânicas básicas, apresentando declividades intermediárias e com espessura variável do solo, chegando a vários metros, representada por colúvios, sedimentos inconsolidados e solo residual de basalto. Nessa faixa altimétrica ocorre o maior número de escorregamentos e com maior magnitude, tais como escorregamentos rotacional e planar, rastejo de solo, fluxo de detritos, escorregamento, quedas (rolamento e tombamento) e erosão laminar.

Na porção da baixa encosta ocorrem rochas vulcânicas básicas, arenitos e sedimentos fluviais, observando-se solos residuais de basalto, colúvios, tálus e sedimentos inconsolidados, com espessuras de solo normalmente menores que os presentes na meia encosta, gerando escorregamento rotacional e planar, rastejo, erosão laminar, solapamento das margens e inundação. As seguintes faixas de altitude foram utilizadas como variáveis espaciais: $20-100 \mathrm{~m}, 100-150 \mathrm{~m}, 150-200 \mathrm{~m}$,
200-250 m, 250-300 m, 300-350 m, 350-400 m, 400-450 m, 450-500 m, 500-550 m, 550-600 m, 600-650 m, 650-720 m

DECLIVIDADE - A tensão cisalhante no solo ou em outro material inconsolidado geralmente aumenta com o aumento da declividade da encosta. Em declividades suaves, é esperada uma baixa frequência de deslizamentos, devido as baixas tensões de cisalhamento associadas aos baixos gradientes. É importante mencionar que a altimetria e declividade são dois fatores condicionantes fundamentais na deflagração de deslizamentos. A altimetria, como descrito anteriormente, controla não só a espessura, mas também a tipologia do solo. A declividade condiciona de forma direta a ocorrência de deslizamentos, uma vez que o aumento do ângulo da encosta implica em uma diminuição do fator de segurança potencializando a ocorrência de deslizamentos. Foram definidas as seguintes variáveis para o fator slope: $0-3 \%, 3-8 \%, 8-13 \%, 13-20 \%$, $20-45 \%, 45-100 \%$ e maior que $100 \%$.

ORIENTAÇÃO - fornece informações sobre a exposição frente às variáveis climáticas, tais como o vento, precipitações atmosféricas e insolação. Dai e Lee (2001) comentam que a orientação das encostas afeta indiretamente a resistência ao cisalhamento, pois está intimamente relacionada à presença de umidade e de cobertura vegetal. Além do que, as precipitações pluviométricas estão condicionadas à direção predominante dos ventos, isto é, a quantidade de chuva será maior nas encostas expostas a estes eventos atmosféricos. Oito faixas de valores azimutais ortogonais à direção das encostas foram consideradas: $\mathrm{N}(337,5-22,5)$, NE $(22,5-$ $67,5), \mathrm{E}(67,5-112,5), \mathrm{SE}(112,5-157,5), \mathrm{S}(157,5-202,5), \mathrm{SW}$ $(202,5-247,5)$, W $(247,5-292,5)$ e NW $(292,5-337,5)$.

LITOLOGIA-Os fatores geológicos que condicionam os movimentos de massa levam em conta o tipo e a distribuição dos materiais que compõem o substrato das encostas. A litologia é o fator controlador do tipo de solo e apresenta diferentes comportamentos quanto à resistência ao cisalhamento e permeabilidade (granulometria, teor de argila, óxidos de ferro, etc.). Frente aos fenômenos de instabilidade, cada litologia comporta-se de forma diferente. O contato entre os derrames ácidos e básicos representa uma quebra de relevo na região e, muitas vezes, encontra-se encoberto por colúvios ou pelo próprio corpo estradal, representando áreas de maior instabilidade.

A partir do mapa geológico regional, foram definidas quatro associações geológicas distintas: Formação Serra Geral Tipo 1 (basaltos tipo Gramado interdigitando superiormente vulcânicas ácidas do tipo Palmas/Caxias); Formação Serra Geral tipo 2 (efusivas toleíticas básico-intermediárias e ácidas, intercalando na base arenitos eólicos intertraps, intrusões e derrames picríticos tipo Gravataí sucedidos por basaltos tipo Gramado); Formação Botucatu (arenitos finos a médios róseoavermelhados); e Depósitos Eluviais/Coluviais (arenitos conglomeráticos, conglomerados, diamictitos, arenitos e lamitos avermelhados, maciços ou com estruturas acanaladas). 
USO DO SOLO E COBERTURA VEGETAL - A cobertura do solo é um dos fatores que influenciam na ocorrência de deslizamentos, deste modo, áreas sem cobertura vegetal são mais propícias a deslizamentos. Áreas com cobertura vegetal tendem a reduzir a infiltração de água meteórica reduzindo o incremento da pressão neutra no solo. A vegetação previne a erosão devido à ação das raízes das árvores, aumentando a resistência do solo. De acordo com Guidicini e Nieble (1984), a atuação da cobertura vegetal na estabilidade de encostas, se dá no sentido de reduzir a intensidade dos agentes climáticos no maciço natural, assim favorecendo a estabilidade das encostas. Segundo Gray (1995) a cobertura vegetal apresenta comportamentos diferenciados quanto à estabilidade das encostas, podendo ser favoráveis e desfavoráveis. Dentre os efeitos favoráveis está a redistribuição da água da chuva nas copas das árvores, o que impede o impacto direto da chuva na superfície do terreno, retardando e diminuindo a quantidade de água que se infiltra no solo. Outro fator favorável é o aumento da resistência do solo devido ao reforço mecânico produzido por raízes pivotantes e profundas (Rickson, 1995). Os efeitos desfavoráveis podem ser descritos como: efeito alavanca, que é a força cisalhante transferida pelos troncos das árvores ao terreno, quando suas copas são atingidas por fortes ventos; efeito cunha, originado pela pressão lateral causada pelas raízes ao penetrar em fendas, fissuras e canais de solo ou rocha; e a sobrecarga vertical causada pelo peso das árvores, principalmente em encostas com alta declividade. De acordo com Santos (2004), a vegetação natural constitui o único fator externo inibidor dos escorregamentos e de todas as formas de movimentação superficial dos terrenos, através dos seguintes aspectos:

- impede a ação direta das gotas de chuva no solo através das copas e da serrapilheira;

- impede a ação erosiva das águas de chuva por meio de raízes superficiais e da serrapilheira;

- retém por molhamento de todo o edifício arbóreo parte da água da chuva que chegaria ao solo;

- dilui no tempo o acesso das chuvas ao solo;

- retira por absorção e devolve à atmosfera por evapotranspiração parte da água infiltrada no solo;

- agrega, "coesiona" e retém os solos superficiais através de uma malha superficial e subsuperficial de raízes.

Para Varnes (1984), a vegetação pode originar efeitos negativos na estabilidade das encostas por: aumentar a sobrecarga vertical nos taludes; aumentar a ação da força dos ventos nas árvores causando um momento de tensões cisalhantes na superfície de ruptura e desagregar o solo através da ação das raízes que dilatam as trincas e favorecem a infiltração.

Para Pradini et al (1976), a vegetação promove estabilidade pois: reduz a ação dos agentes climáticos, protegendo o solo das precipitações, vento e irradiação solar; retém uma umidade razoável de água da chuva e elimina água por meio de evapotranspiração; o escoamento superficial e a erosão diminuem e há um aumento da resistência ao cisalhamento no talude graças às raízes das plantas. Foram definidas as seguintes classes de cobertura do solo: mata, solo exposto, campo, culturas anuais, água e sombra.

DISTÂNCIAADRENAGENS - A elevada declividade longitudinal dos afluentes principais e o caráter nitidamente encaixado dos talvegues contribuem para concentrar rapidamente as águas originárias das chuvas, resultando em locais de erosão acentuada e umidade elevada, podendo levar à ruptura das encostas.

A partir das drenagens, foram definidas distâncias que foram utilizadas como variáveis: $0-15 \mathrm{~m}, 15-50 \mathrm{~m}, 50-100 \mathrm{~m}$ e maior do que $100 \mathrm{~m}$.

DISTÂNCIA E ESTRADAS - Áreas próximas ao sistema viário podem sofrer influência relativa à execução de cortes inadequados das encostas, realizados na abertura das estradas. A presença da rodovia modifica os padrões naturais de fluxo d'água. As águas que surgem nos cortes em rocha são geralmente mal drenadas e infiltram-se nas camadas granulares do aterro do corpo estradal. A ausência de um sistema de drenagem de pista em diversos locais permite que o fluxo se dê pela base do aterro, ou por vezes pelo subleito do pavimento, surgindo na crista ou na base dos taludes. Esses fenômenos resultam em aumento de poro-pressões ou mesmo em processos erosivos (piping) que promovem subsidências ao longo da estrada.

A partir do sistema viário, foram definidas distâncias, que foram utilizadas como variáveis: $0-15 \mathrm{~m}, 15-50 \mathrm{~m}, 50-$ $100 \mathrm{~m}$ e maior do que $100 \mathrm{~m}$.

\section{E2 - Criação da base cartográfica digital}

O primeiro passo para a análise de suscetibilidade foi estruturar a base cartográfica digital, constituída pelos planos de informação relativos aos fatores altimetria, declividade, orientação, litologia, uso do solo e cobertura vegetal, distância a drenagens, distância a estradas e o plano de informação inventário de deslizamentos.

O material e equipamentos utilizados para o desenvolvimento da base de dados foram os seguintes:

- carta planialtimétrica, em escala 1:50.000;

- fotografias aéreas, em escala 1:10.000;

- mapa geológico, em escala 1:250.000;

- imagem do sensor ASTER;

- cadastro de deslizamentos;

- programas computacionais de edição, digitalização vetorial, geoprocessamento e processamento de imagens de satélite;

- aparelho receptor GPS (Global Positioning System) de navegação. 
Para a geração do PI INVENTÁRIO, contendo as cicatrizes de deslizamentos, foram utilizadas fotografias aéreas, imagem do sensor ASTER e o cadastro com a descrição e a localização espacial dos pontos. Este plano de informação foi usado para calibrar o modelo conceitual, uma vez que áreas com ocorrência registrada de deslizamentos possuem características potencialmente favoráveis a tais processos.

O PI ALTIMETRIA foi considerado na forma de Modelo Digital de Terreno (MDT). A geração do MDT foi feita por interpolação usando a Krigagem, com os valores extraídos das curvas de nível digitalizadas da carta planialtimétrica. A partir do MDT, foi realizada a análise geomorfométrica, onde foram gerados os PIs DECLIVIDADE E ORIENTAÇÃO.

O PI LITOLOGIA foi gerado a partir da digitalização dos polígonos contendo as unidades litológicas extraídas do mapa geológico regional, importados como arquivo vetorial, convertidos para o formato raster e georreferenciados.

Para o PI USO DO SOLO E COBERTURA VEGETAL foi realizada a classificação supervisionada da imagem ASTER, onde foram utilizadas as bandas 1,2 e $3 \mathrm{~N}$ em tons de cinza e a composição colorida R2G3B1 obtidas destas bandas.

O sensor ASTER é fruto de uma cooperação entre o Japão e os Estados Unidos da América, no qual os japoneses foram responsáveis pela construção do sensor e os norteamericanos pelo satélite. A plataforma Terra, que carrega o sensor ASTER, foi lançada em 18 de dezembro de 1999, em órbita sol-síncrona, altitude de $705 \mathrm{~km}$, período orbital de 98,9 minutos e cobertura total da Terra em 16 dias. Uma cena imageada pelo sensor ASTER tem dimensões de 60 x 60km.O ASTER é formado pelos seguintes subsistemas: Visível e Infravermelho Próximo (VNIR), com três bandas e resolução espacial de 15 metros; Infravermelho Médio (SWIR), com seis bandas e resolução espacial de 30 metros; e Infravermelho Termal (TIR), com cinco bandas e resolução espacial de 90 metros.

Foram colhidas amostras de cada classe, através do pré-conhecimento das características da região, permitindo a identificação das áreas ocupadas por mata, solo claro, solo escuro, campo, culturas anuais, água e sombra, nas imagens visualizadas em tela, gerando um arquivo vetorial, sendo posteriormente obtido o arquivo de assinaturas multiespectrais. Na classificação supervisionada foi usado o método da máxima verossimilhança através da aplicação de uma função de densidade de probabilidade sobre $\mathrm{o}$ arquivo de assinaturas. $\mathrm{O}$ arquivo classificado foi ainda submetido a uma reclassificação, para agrupar as classes solo claro e solo escuro. Estas duas classes foram inicialmente separadas devido à diferença espectral, buscando uma maior acurácia na classificação.

Os PIs DISTÂNCIAA DRENAGENS E DISTÂNCIA A ESTRADAS, foram gerados a partir da digitalização destas informações na base planialtimétrica. Os arquivos vetoriais foram convertidos para o formato raster, georreferenciados e a partir de operadores de distância (buffer), foram definidas distâncias em relação aos cursos d'água e sistema viário.

\section{E3 - Análise estatística e espacial}

Após a geração dos planos de informação foi realizada uma tabulação cruzada entre cada um dos PIs relativos aos fatores e o PI inventário, sendo necessário estar todos eles no formato raster, georreferenciados, com o mesmo número de linhas e colunas, a mesma resolução espacial e a mesma escala.

A partir da ocorrência de deslizamentos dentro da área de cada variável analisada foi realizado o cálculo estatístico, conforme mostrado na Tabela 2.

\section{Tabela 2 - Resultados obtidos através da tabulação cruzada}

\begin{tabular}{|c|c|c|c|c|}
\hline Fator & Variável & Area \% & N8 ocorrências & Pes \\
\hline \multirow{7}{*}{ Declividade } & 0.3 & 1.72 & 0 & 0.00 \\
\hline & 3.8 & 9.01 & 1 & 0.01 \\
\hline & $8-13$ & 9.05 & 0 & 0.00 \\
\hline & 13.20 & 14.67 & 2 & 0.03 \\
\hline & 20.45 & 49.27 & 29 & 0.43 \\
\hline & $45 \cdot 100$ & 16.18 & 34 & 0.51 \\
\hline & $>100$ & 0.11 & 0 & 0.00 \\
\hline \multirow{13}{*}{ Altimetna } & $20 \cdot 100$ & 7.25 & 0 & 0.00 \\
\hline & $100-150$ & 6.39 & 0 & 0.00 \\
\hline & $150-200$ & 7.35 & 2 & 0.03 \\
\hline & $200-250$ & 6.87 & 7 & 0.10 \\
\hline & $250-300$ & 7.59 & 12 & 0.18 \\
\hline & $300-350$ & 12.76 & 6 & 0.09 \\
\hline & $350-400$ & 12.18 & 4 & 0.06 \\
\hline & $400-450$ & 9.09 & 8 & 0.12 \\
\hline & $450-500$ & 7.79 & 5 & 0.07 \\
\hline & $500-550$ & 6.84 & 6 & 0.09 \\
\hline & $550-600$ & 5.52 & 6 & 0.09 \\
\hline & $600-650$ & 5.93 & 6 & 0.09 \\
\hline & 650.720 & 4.43 & 4 & 0.06 \\
\hline \multirow{8}{*}{ Onentaçă 0} & $N$ & 11.44 & 2 & 0.03 \\
\hline & NE & 12.96 & 1 & $0.00:$ \\
\hline & $\mathrm{E}$ & 14.22 & 3 & 0.04 \\
\hline & SE & 13.75 & 17 & 0.25 \\
\hline & $\mathrm{S}$ & 13.82 & 3 & 0.04 \\
\hline & SW & 13.17 & 3 & 0.04 \\
\hline & $w$ & 11.71 & 20 & 0.30 \\
\hline & NW & 8.94 & 17 & 0.25 \\
\hline \multirow{4}{*}{ Litologia } & FmSG $\beta 1$ & 20.99 & 21 & 0.31 \\
\hline & $\mathrm{FmSG} \alpha \mathrm{l}$ & 69.71 & 45 & 0.68 \\
\hline & $\mathrm{FmBt}$ & 5.45 & 0 & 0.00 \\
\hline & DepEC & 3.84 & 0 & 0.00 \\
\hline \multirow{6}{*}{$\begin{array}{l}\text { Uso do solo e } \\
\text { cobertura vegetal }\end{array}$} & Mata & 43.54 & 49 & 0.74 \\
\hline & Solo exp osto & 21.76 & 6 & 0.09 \\
\hline & Campo & 23.33 & $\frac{0}{5}$ & 0.07 \\
\hline & Culturas anuais & 9.19 & 1 & 0.01 \\
\hline & Água & 0.16 & 0 & 0.00 \\
\hline & Sombra & 2.12 & 5 & 0.07 \\
\hline \multirow{4}{*}{$\begin{array}{l}\text { Distância a } \\
\text { crenagens }\end{array}$} & 0.15 & 2.8 & 0 & 0.00 \\
\hline & 15.50 & 18.05 & 22 & 0.33 \\
\hline & $50 \cdot 100$ & 18.14 & 13 & 0.19 \\
\hline & $>100$ & 61.01 & 31 & 0.46 \\
\hline \multirow{4}{*}{$\begin{array}{c}\text { Distância a } \\
\text { estradas }\end{array}$} & 0.15 & 3.36 & 2 & 0.03 \\
\hline & 15.50 & 20.89 & 21 & 0.31 \\
\hline & $50-100$ & 18.23 & 8 & 0.12 \\
\hline & $>100$ & 57.52 & 35 & 0.53 \\
\hline
\end{tabular}

O peso das variáveis não foi obtido dividindo pela área inteira estudada. O peso foi definido pela relação entre densidade de deslizamentos ocorridos dentro da área de cada variável pelo ${ }^{\circ}$ total de ocorrências de deslizamentos. No exemplo citado para o fator cobertura do solo, na 
classe mata foram observados 49 dos 66 deslizamentos ou seja $74,24 \%$ dos deslizamentos ocorrem na classe mata não levando em consideração o tamanho da área que, para a classe mata, é de $43 \%$. Neste caso, há uma tendência de se encontrar o maior número de deslizamentos devido ao tamanho da classe. O tamanho da área foi considerado na etapa de ponderação dos planos de informação, que entre outros aspectos, foi diminuída a importância relativa para as áreas excessivamente grandes. Por outro lado, na classe mata é esperada a maioria das ocorrências, uma vez que as classes solo exposto e campo e culturas anuais normalmente apresentam declividades suaves. Somando-se a área das classes, onde há menor expectativa de deslizamentos (solo exposto, campo, culturas anuais e água), tem-se $54 \%$ da área de estudo e apenas 17 ocorrências em 66 mapeadas, ou seja, $26 \%$ das ocorrências.

O mesmo exemplo serve para o fator declividade em que $49,27 \%$ da área correspondente a classe entre 20 e $45 \%$. A classe com maior $\mathrm{n}^{\circ}$ de ocorrências, está no entanto, é a classe entre 45 e $100 \%$ com $51,52 \%$ das ocorrências com uma área de apenas 16,18\% do total (Vanacôr, 2006).

O peso das variáveis foi calculado pela densidade de deslizamentos ocorridos dentro da área de cada variável em relação à densidade de deslizamentos ocorridos na área inteira, como mostra a fórmula abaixo, sendo a soma das variáveis de cada fator igual a 1 .

$$
\mathrm{Wvi}=\mathrm{Lvi} / \mathrm{L}
$$

Onde:

Wvi - Peso da variável i

Lvi - Número de ocorrências de deslizamentos envolvendo a variável $\mathrm{i}$

L - Número total de ocorrência de deslizamentos na área

E4 - Padronização dos planos de informação

O próximo passo foi padronizar os planos de informação para torná-los comparáveis entre si. Todos foram reduzidos a uma escala padrão variando entre 0 e 255 , representando o intervalo de um byte, tendo como base os resultados estatísticos obtidos na tabulação cruzada.

Para a padronização, foi utilizado o conceito probabilístico Fuzzy, permitindo a retenção das características de dados contínuos, onde 0 representa o valor menos susceptível a deslizamentos e 255 o valor mais susceptível.

Os PIs LITOLOGIA, USO DO SOLO E COBERTURA VEGETAL e ORIENTAÇÃO foram ponderados por pesos entre 0 e 255 (membros fuzzy), obtidos a partir de equações lineares.

Para a ponderação PIs DISTÂNCIA A DRENAGENS E DISTÂNCIAA ESTRADAS, foi aplicada uma função qua- drática sobre cada grade de distância para definir os valores dos membros fuzzy destes planos de informação. A função quadrática busca modelar a importância das drenagens e rodovias à medida que se afasta dos mesmos, a menor distância recebeu o valor 255 .

O PI DECLIVIDADE foi reescalonado de forma linear e crescente, a maior declividade recebeu o valor 255 .

O PI ALTIMETRIA foi reescalonado de forma linear e simétrica, tendo as classes intermediárias de elevação recebido valores de 255 .

\section{E5 - Ponderação dos planos de informação}

Para determinação dos pesos de cada um dos fatores ambientais foi utilizada a técnica AHP (Analytical Hierarchy Process), desenvolvida por Saaty (1987), baseada na lógica da comparação pareada. Esta técnica permite diminuir a subjetividade do processo de julgamento da importância dos pesos e expressar o processo quantitativamente.

Depois de cada plano de informação estar reduzido a uma escala contínua e comparável, buscou-se determinar um conjunto ótimo de pesos, estabelecendo qual dos fatores é mais importante e quanto cada um deles é mais importante que cada um dos outros.

Inicialmente, os diferentes fatores foram comparados dois a dois, e um critério de importância relativa foi atribuído ao relacionamento entre estes fatores, conforme escala prédefinida, mostrada na Tabela 3.

A definição da importância relativa de cada fator no que se refere à suscetibilidade a deslizamentos baseou-se na experiência e conhecimentos específicos de pesquisadores e geólogos de engenharia da Fundação de Ciência e Tecnologia (CIENTEC), que após a análise dos resultados estatísticos obtidos na fase tabulação cruzada e discussões buscando a compreensão das variáveis envolvidas no processo chegaram a um consenso sobre o peso relativo atribuído para cada fator.

\section{Tabela 3 - Escala de valores AHP para definição da importância relativa dos fatores}

\begin{tabular}{|c|c|}
\hline $\begin{array}{l}\text { Intensidade de } \\
\text { importância }\end{array}$ & Definição e explicaçăo \\
\hline 1 & $\begin{array}{l}\text { Importancia igual - os dois fatores contribuem igualmente } \\
\text { para o objetivo }\end{array}$ \\
\hline 3 & $\begin{array}{l}\text { Importância moderada - um fator é ligeir amente mais } \\
\text { importante do que o outro }\end{array}$ \\
\hline 5 & $\begin{array}{l}\text { Importância essencial - um fator è claramente mais } \\
\text { importante do que o outro }\end{array}$ \\
\hline 7 & $\begin{array}{l}\text { Importância demonstrada - um fator è fortemente favorecido } \\
\text { e sua maior relevância foi demonstrada na prática }\end{array}$ \\
\hline 9 & $\begin{array}{l}\text { Importancia extrema - a evidéncia que diferencia os fatores } e \\
\text { da maior ordem possivel }\end{array}$ \\
\hline $2,4,6,8$ & $\begin{array}{l}\text { Valores intermediários entre julgamentos-possibilidade de } \\
\text { compromissos adicionais }\end{array}$ \\
\hline
\end{tabular}


A relação de importância relativa entre os fatores foi utilizada como dado de entrada em uma matriz de comparação pareada, onde foram calculados os autovalores e autovetores da matriz. Os pesos são obtidos por meio do autovetor principal da matriz de comparação pareada, mostrada na Tabela 4.

Tabela 4 - Matriz de comparação pareada - Técnica AHP

\begin{tabular}{|ccc|c|ccc|c|}
\hline Fatores & f_dec & f_geo & f_via & f_uso & f_hid & f_alt & F_ori \\
\hline f_dec & 1 & & & & & & \\
\hline f_geo & $1 / 2$ & 1 & & & & & \\
f_via & $1 / 3$ & $1 / 2$ & 1 & & & & \\
f_uso & $1 / 2$ & 1 & 2 & 1 & & & \\
f_hid & $1 / 3$ & $1 / 2$ & 1 & $1 / 2$ & 1 & & \\
\hline f_alt & $1 / 9$ & $1 / 5$ & $1 / 2$ & $1 / 5$ & $1 / 2$ & 1 & \\
\hline f_ori & $1 / 9$ & $1 / 5$ & $1 / 2$ & $1 / 5$ & $1 / 2$ & 1 & 1 \\
\hline
\end{tabular}

A AHP é uma teoria com base matemática, que além de permitir a organização e avaliação da importância relativa entre critérios mede a consistência dos julgamentos. $\mathrm{O}$ valor da razão de consistência obtido para a matriz acima foi 0,00 , indicando a completa consistência no processo de julgamento.
E6 - Avaliação por critérios múltiplos

Para integrar as informações contidas em cada um dos mapas de fatores foi realizada uma combinação linear ponderada, realizada através de um módulo de suporte a decisão MCE (Multi Criteria Evaluation) do programa computacional SIG.

Os pesos obtidos a partir da matriz de comparação pareada AHP, foram usados como coeficientes e multiplicados pelo respectivo plano de informação, sendo posteriormente realizada a soma dos produtos, como é mostrado na equação abaixo. Deste modo, no mapa de susceptibilidade a deslizamentos, cada pixel representa a nota recebida considerando todos os fatores escolhidos e os pesos atribuídos a eles.

$\mathrm{MS}=\left(\mathrm{f} \_\mathrm{slo} * \mathrm{wslo}+\mathrm{f} \_\mathrm{geo} * \mathrm{wgeo}+\mathrm{f} \_\right.$road $* \mathrm{wroad}+\mathrm{f}$ land*wland + f_dre*wdre + f_ele*wele + f_asp*wasp) $/ 7$

A estruturação dos níveis compostos pelas variáveis e pelos fatores selecionados, com seus respectivos pesos e a combinação entre eles para chegar ao mapa de susceptibilidade é representada na Figura 3.

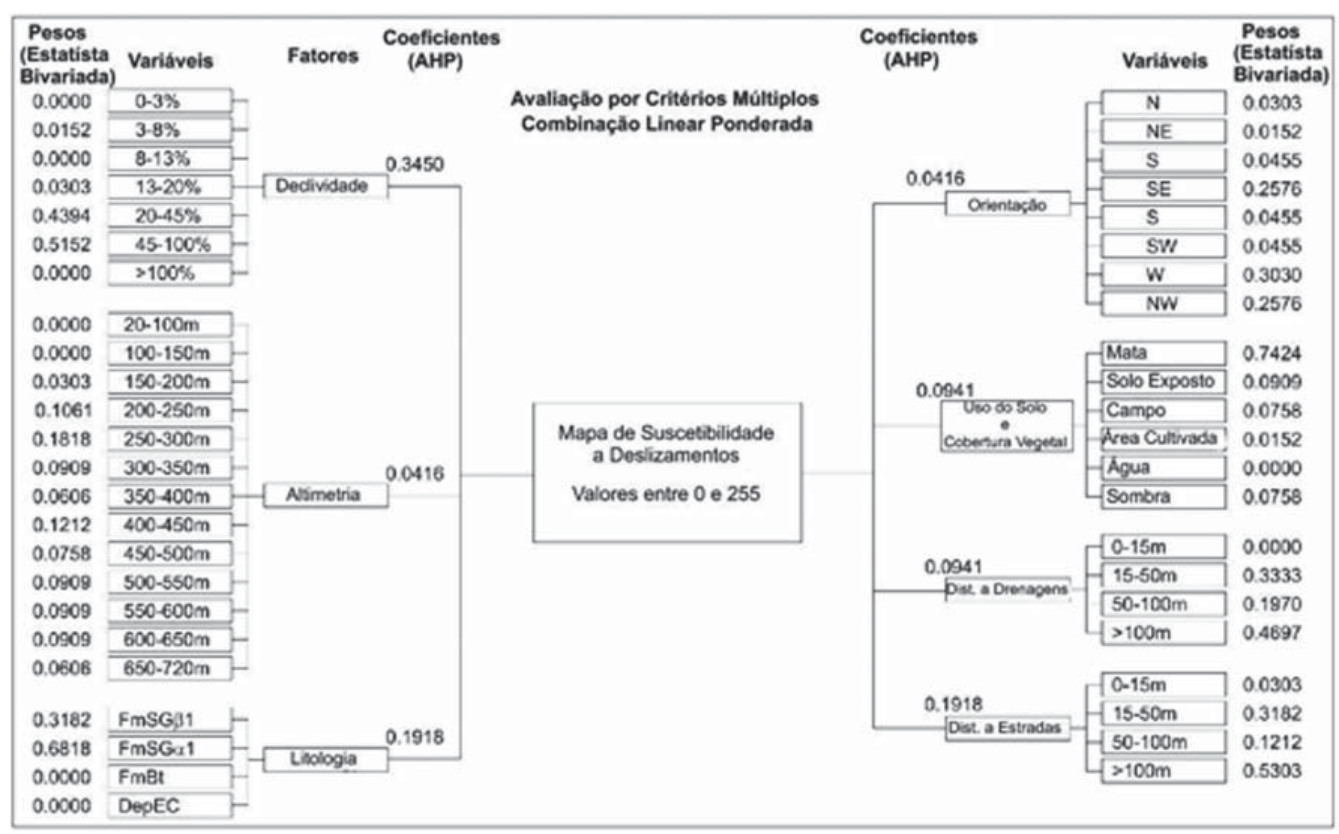

Figura 3 - Estruturação dos níveis compostos para Avaliação por Critérios Múltiplos e Combinação Linear Ponderada. 
A Figura 4 mostra o mapa de susceptibilidade a deslizamentos para a área de estudo obtida a partir da metodologia adotada, apresentando uma grade numérica de forma contí- nua, com valores variando entre 0 e 255 , de menos a mais suscetível a deslizamentos.
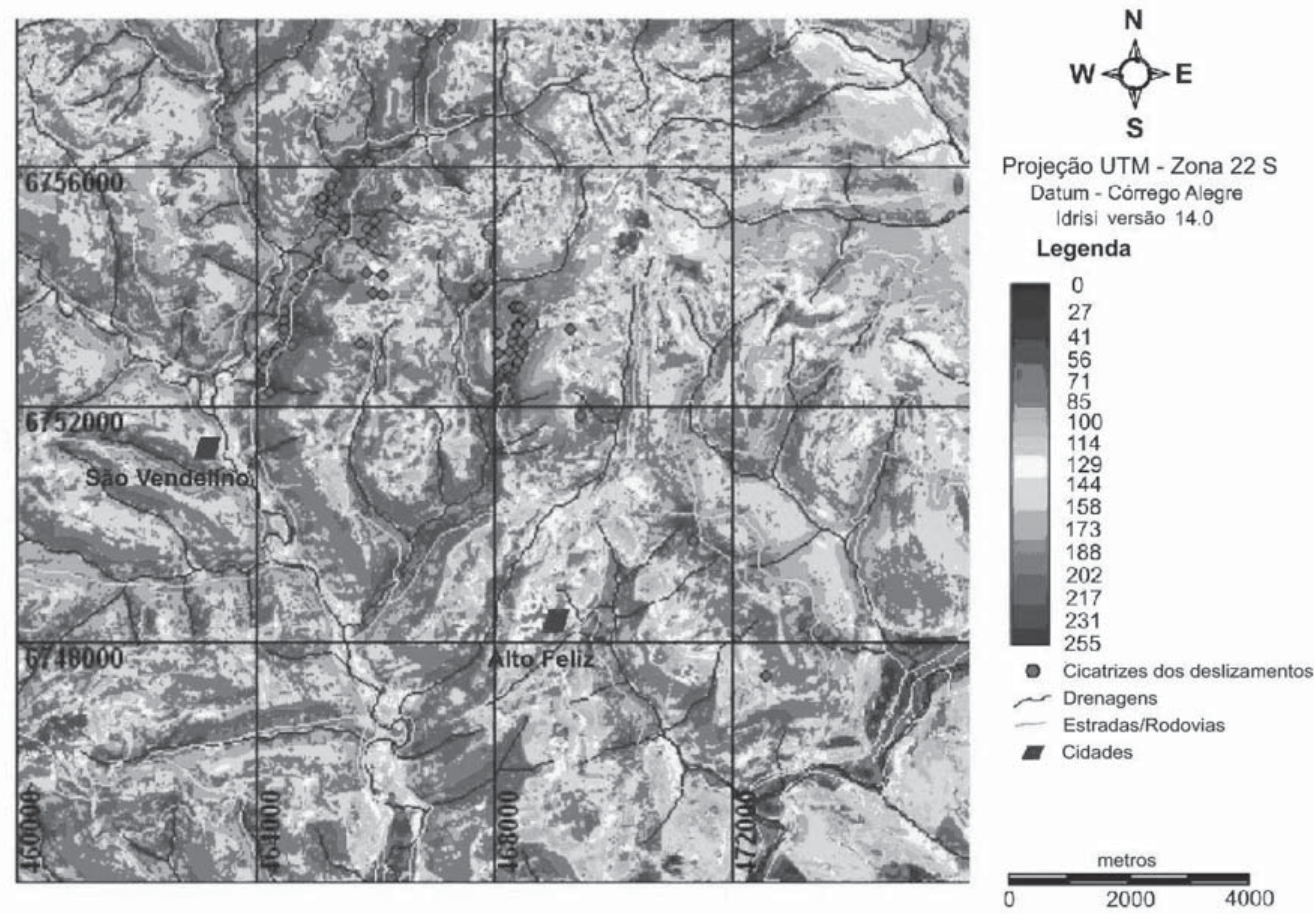

Figura 4 - Mapa de suscetibilidade a deslizamentos com valores contínuos.

E7 - Definição e caracterização dos graus de suscetibilidade

A partir da grade numérica contínua da variação da grandeza suscetibilidade a deslizamentos, foi realizada a reclassificação pelo método do desvio quartílico, dividindo a imagem original em quatro intervalos de suscetibilidade de 0 a 63 (classificada como baixa suscetibilidade), de 63 a 127 (média suscetibilidade), de 127 a 191 (suscetibilidade alta) e de 191 a 255 (classificada como suscetibilidade muito alta).

O fatiamento dos graus de suscetibilidade foi realizado a partir da reclassificação da imagem original, resultando no mapa de graus suscetibilidade a deslizamentos para a área de estudo, conforme pode ser visto na Figura 5.

A Tabela 5 mostra a distribuição da área por graus de suscetibilidade, onde pode ser observado que a maior parte da área de estudo $(56,47 \%)$ apresenta alto grau de suscetibilidade. Áreas com suscetibilidade muito alta, correspondem a 25,10\% do total da área, restando $16,84 \%$ para a suscetibilidade média e apenas $1,59 \%$ para áreas de baixa suscetibilidade.

\section{Tabela 5 - Distribuição da área por graus de suscetibilidade}

\begin{tabular}{|c|c|c|}
\hline $\begin{array}{c}\text { Suscetibilidade a } \\
\text { movimentos de massa }\end{array}$ & Área (ha) & $\%$ \\
\hline Baixa & 367,81 & 1,59 \\
\hline Média & 3900,80 & 16,84 \\
& & 56,47 \\
\hline Alta & 13086,38 & 25,10 \\
\hline Muito alta & 5814,52 & 100 \\
\hline Total & 2,3169 & \\
\hline
\end{tabular}

Após a definição dos graus de suscetibilidade, cada plano de informação foi comparado com o modelo final de suscetibilidade através de uma tabulação cruzada, e a partir dos resultados foi possível fazer uma síntese das características de cada uma das classes de suscetibilidade. Os resultados da tabulação cruzada são mostrados na Tabela 6 , onde a área e o percentual das classes de cada fator analisado são representados em relação à área total de cada um dos diferentes graus de suscetibilidade. 


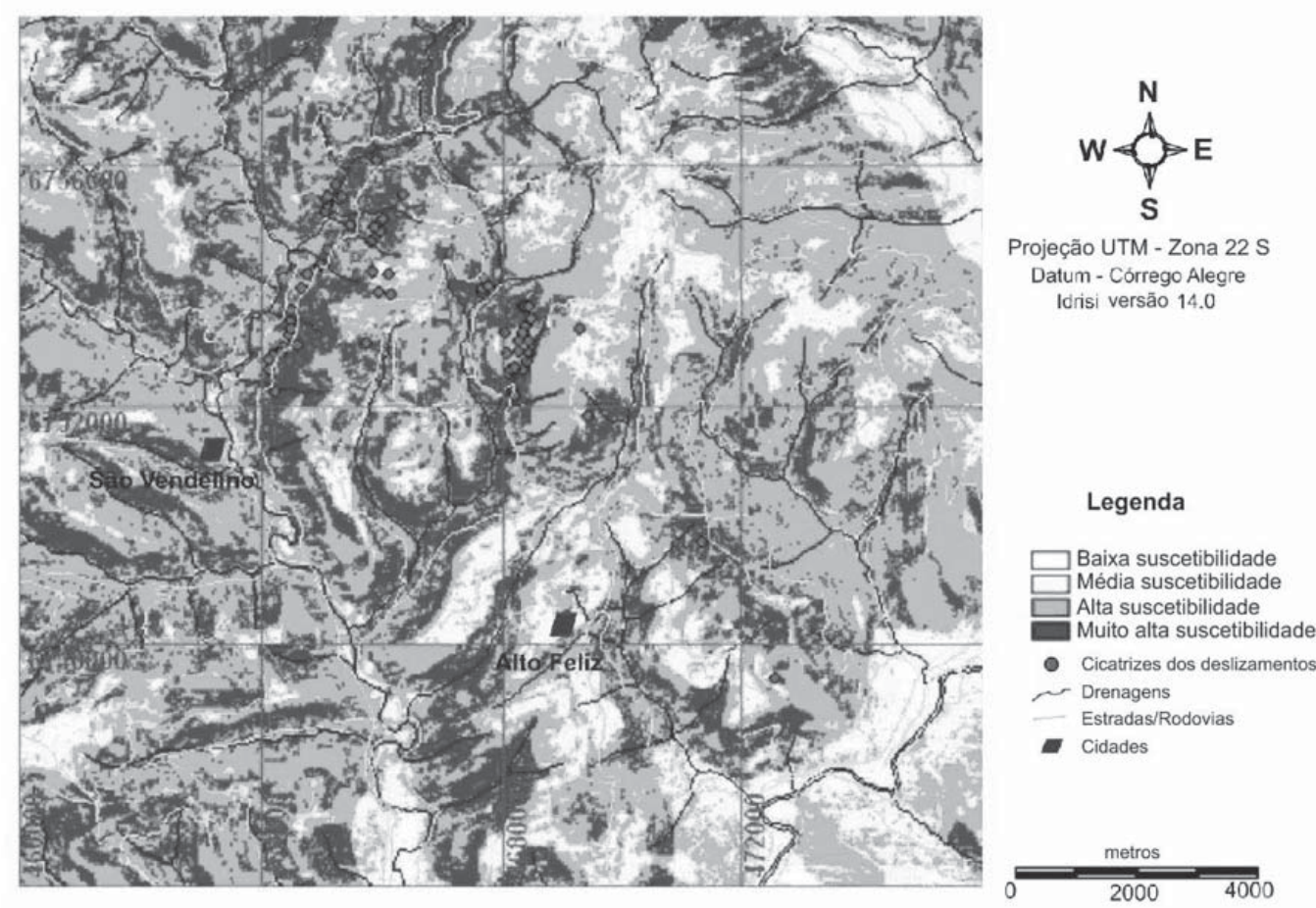

Figura 5 - Mapa de suscetibilidade a deslizamentos com definição dos diferentes graus.

Tabela 6 - Comparação entre os fatores analisados e o mapa final em graus de suscetibilidade a movimentos de massa, através da tabulação cruzada.

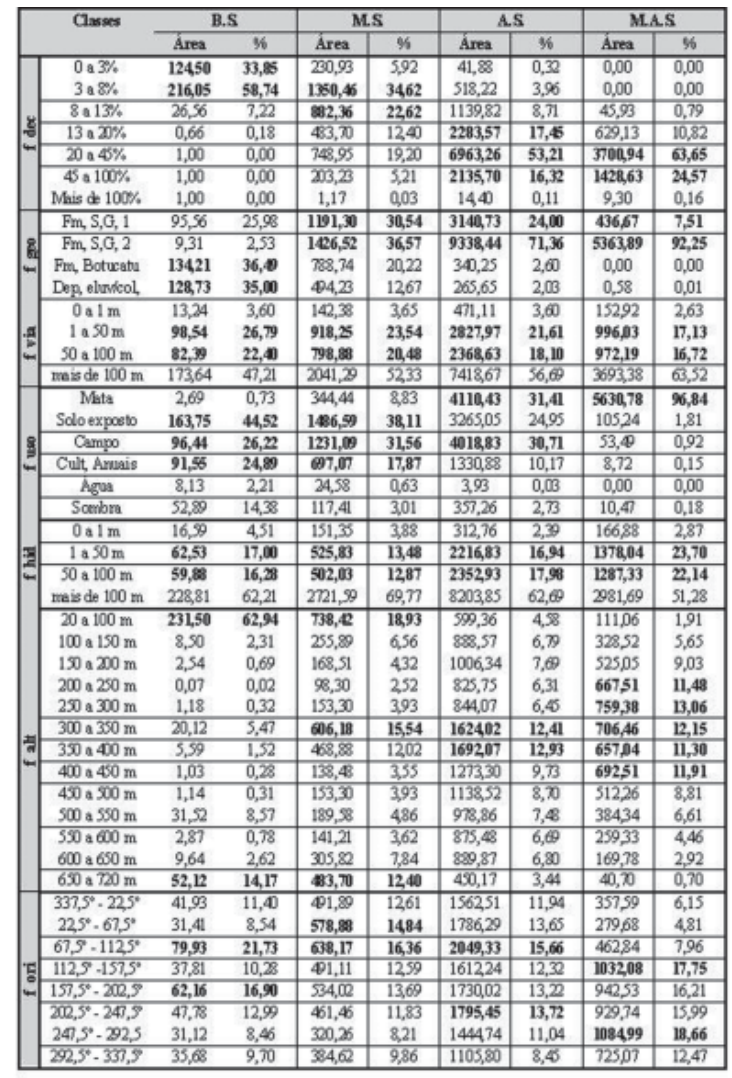

A Tabela 7 mostra uma síntese das características relativas à geologia, relevo, uso e ocupação do solo de cada classe (grau) de suscetibilidade na área de estudo, onde foram consideradas as limitações quanto à ocupação e uso dessas áreas.

Tabela 7 - Caracterização das classes de suscetibilidade a movimentos de massa.

\begin{tabular}{|c|c|c|c|}
\hline $\begin{array}{c}\text { Baixa } \\
\text { Suscetibilidade }\end{array}$ & $\begin{array}{c}\text { Média } \\
\text { Suscetibilidade }\end{array}$ & $\begin{array}{c}\text { Alta } \\
\text { Suscetibilidade }\end{array}$ & $\begin{array}{c}\text { Muito Alta } \\
\text { Suscetibilidade }\end{array}$ \\
\hline 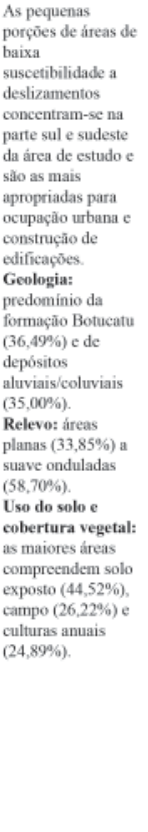 & 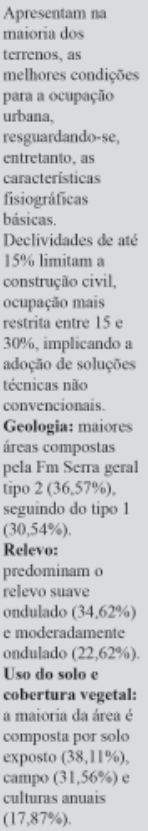 & 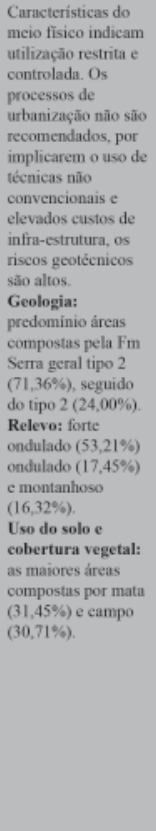 & 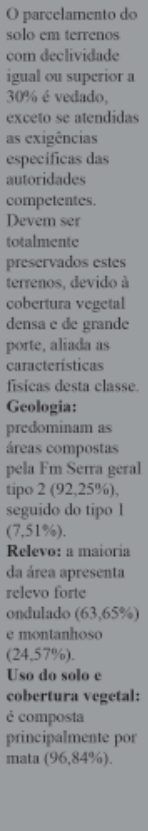 \\
\hline
\end{tabular}


E8 - Verificação da acurácia

Por fim, foi realizada uma verificação em campo com o objetivo de avaliar e comparar o produto cartográfico com a realidade observada no terreno.

Foram escolhidos, aleatoriamente, pontos em áreas de muito alta susceptibilidade e extraídas suas coordenadas de mapa, que posteriormente, foram verificados com uso de GPS, no campo. Nos locais observados as áreas avaliadas realmente são condizentes com o mapa, apresentando características geológico-geotécnicas com potencial para a ocorrência de deslizamentos.

Em alguns pontos de muito alta susceptibilidade avaliados, foi observada a presença de deslizamentos não levantados na fase de inventário.

\section{Discussão dos Resultados}

Os resultados obtidos, analisados segundo a aplicabilidade do Sistema de Informações Geográficas e do Sensoriamento Remoto e à luz da metodologia adotada, demonstram que a área de estudo apresenta em sua maior parte uma alta suscetibilidade a deslizamentos, tendo como principais condicionantes naturais e antrópicos a declividade, a geologia e distância ao sistema viário. Considerando que grande parte das cicatrizes está relacionada a precipitações ocorridas em dezembro de 2000 e a partir das variáveis ambientais utilizadas na pesquisa, a síntese da influência das condicionantes mostra a declividade como fator essencial na ocorrência dos processos. Pode-se observar que a maior frequência de deslizamentos encontra-se situada nas classes com declividades entre 20 e $45 \%$ e 45 e $100 \%$, com relevo classificado como forte ondulado e montanhoso, respectivamente, demonstrando relação direta com a espessura do solo, uma vez que nas encostas mais íngrimes (relevo escarpado) os solos já foram removidos por deslizamentos anteriores. Analisando a correlação entre o fator declividade e o mapa de suscetibilidade, estas duas classes são as mais significativas na definição das áreas de alta e muito alta suscetibilidade.

Para o fator litologia, controlador primário do tipo de solo, as áreas formadas pela classe das efusivas toleíticas básico-intermediárias e ácidas, intercalando na base arenitos eólicos intertraps, foram as que apresentaram maior importância como fator definidor da suscetibilidade, com mais de dois terços das ocorrências de deslizamentos situadas nesta classe, ficando comprometida à correlação direta, devido a grande área ocupada pela mesma. $\mathrm{O}$ elevado peso desta classe pode estar relacionado às características de sucessão de derrames, com a presença frequente de estruturas de fluxo, brechações hidráulicas subhorizontais e subverticais, zonas vesiculares e amigdalóides, com elevada suscetibilidade ao intemperismo, alterando-se facilmente e gerando um material de fácil desagregação. Estas estruturas resultam em uma maior fragilidade do solo, maior umidade e menor resistência ao cisalhamento.
Áreas próximas a estradas demonstraram uma alta incidência de deslizamentos, com praticamente metade dos eventos da área de estudo ocorrendo a uma distância de até 100 metros do sistema viário, demonstrando a maior suscetibilidade destas áreas devido à erosão acentuada e aos cortes inadequados.

Entre os condicionantes menos significativos para a definição de suscetibilidade, no fator uso e ocupação do solo e cobertura vegetal, a classe mata representa mais de $70 \%$ das ocorrências de deslizamentos, sendo a classe mais significativa para a definição das áreas de muito alta suscetibilidade.

Para o fator altimetria, as classes representadas pelas médias encostas com altitudes no intervalo entre 200 e 450 metros foram as que tiveram maior ocorrência de deslizamentos. O elevado peso destas classes pode ser atribuído por caracterizarem-se por áreas com as maiores espessuras de solo que aliadas a declividades favoráveis, tornam-se mais propensas à deflagração dos eventos.

$\mathrm{O}$ fator proximidade a drenagens demonstrou uma alta frequência de deslizamentos, com quase metade dos eventos da área de estudo estarem situados a uma distância de até 100 metros dos cursos d'água, demonstrando a maior suscetibilidade destas áreas devido à erosão acentuada, forma da encosta e elevada umidade.

Em relação à orientação, as encostas com maior quantidade de deslizamentos foram as com direções sudeste, oeste e noroeste, os pesos mais elevados atribuídos a estas classes podem estar relacionados às direções de fraturamento e em decorrência de estarem mais expostas as condições climáticas.

\section{Conclusões}

A técnica AHP, para inferência geográfica, apresentou resultados satisfatórios, demonstrando uma correlação alta de $60,61 \%$ entre deslizamentos e áreas de muito alta susceptibilidade (40 dos 66 movimentos de massa constantes no inventário estão em áreas de muito alta susceptibilidade) e $37,88 \%$ dos deslizamentos estão em áreas de alta suscetibilidade. Com a utilização dessa técnica foi possível diminuir a subjetividade do processo de atribuição de pesos para os fatores, no mapa de suscetibilidade.

O Sistema de Informações Geográficas e Sensoriamento Remoto aplicados a áreas de suscetibilidade a deslizamentos, mostraram-se ferramentas poderosas, desde a geração e análise dos dados, até a obtenção dos resultados, facilitando e agilizando o processo de elaboração dos mapas temáticos e mapas de suscetibilidade. Com o SIG também foi possível o cruzamento dos dados levantados e a formulação de testes estatísticos para avaliação e análise dos fatores de forma rápida, sendo fácil realizar a sobreposição de diversos mapas gerados a partir de bases em diferentes escalas.

Para trabalhos futuros, a inclusão de outras informações na base cartográfica digital, possibilitará a avaliação de outros fatores importantes para a representação do modelo conceitual, tais como a forma da encosta, tipo e espessura 
de solos, distância a estruturas geológicas e oscilação do lençol freático, que certamente exercem uma atuação direta na deflagração dos processos de deslizamentos.

É recomendada também a realização de pesquisas em outras áreas-teste com potencial a deslizamento, na serra do Rio Grande do Sul, com características geológico-geotécnicas distintas para que se possa comparar a influência dos fatores.

A pesquisa realizada demonstra a necessidade do aprimoramento de técnicas e propostas metodológicas para elaboração de mapas de suscetibilidade na região da serra do Rio Grande do Sul, buscando análises mais quantitativas, a partir da inclusão de dados aqui não utilizados, que podem trazer uma melhora nas estimativas das áreas de suscetibilidade a movimentos de massa, bem como, a inserção de informações para a determinação das consequências causadas por estes fenômenos (cartas de risco a movimentos de massa). A elaboração de mapas mais completos, trazendo recomendações de uso e ocupação mais específicos possibilitará a geração de mapas com finalidades diversas, que sirvam de suporte a decisões específicas, levando à documentos mais completos e de aplicação mais abrangente.

\section{Referências Bibliográficas}

AUGUSTO FILHO, O. e WOLLE, C.M. Cartas de risco de escorregamentos: uma proposta metodológica e sua aplicação no município de Ilha Bela, SP. São Paulo: ABGE, Revista Solos e Rochas, v.19, n.1, p.45-62, 1996.

CLERICI, A.; PEREGO, S.; TELLINI, C.; VESCOSI, P. A GIS-based automated procedure for landslide susceptibility mapping by Conditional Analysis method: the Baganza valley case study (Italian Northern Apennines). Environment Geology, n.50, p.941-961, 2006.

CRUDEN, D.M. A simple definition of a landslide. Bulletin of the International Association of Engineering Geology, n.43, p.27-29, 1991.

DAI, F.C. e LEE, C.F. Landslide characteristics and slope instability modeling using GIS, Lantau Island, Hong Kong. Geomorphology, v.42, n.3-4, p.213-228, 2001.

DONATI, L. e TURRINI, M.C. An objective method to rank the importance of the factors predisposing to landslides whith the gis methodology: aplication to area of the Apennines (Valnerina, Perugia, Italy). Engineering Geology, v.63, p. 77-289, 2002.

FERNANDES, N.F. e AMARAL, C.P. Movimentos de massa uma abordagem geológica-geomorfológica. In: Guerra, A.J.T.; Cunha, S.B. (Eds.) Geomorfologia e meio ambiente. Rio de Janeiro: Bertrand Brasil, Cap.3, p.123-194, 2003.

FERNADES, N.F.; GUIMARÃES, R.F.; GOMES, R.A.T.; VIEIRA, B.C.; MONTGOMERY, B.R.; GRIMBERG, H. Condicionantes Geomorfológicos dos Deslizamentos nas Encostas: Avaliação de Metodologias e Aplicacão de Modelo de Previsão de Áreas Susceptíveis. Revista Brasileira de Geomorfologia, v.2, n.1, p.51-71, 2001.

FREIRE, E.S.M. Movimentos Coletivos de Solos e Rochas e sua Moderna Sistemática. Construção, n.8 p.10-18, 1965.

GRAY, D. Influence of vegetation on the stability of slopes. In:
International Conference on the Interaction of Vegetation with Natural and Formed Slopes, 1994. Oxford Proceeding... London: Thomas Telford p.2-25, 1995.

GUDICINI, G e NIEBLE, C.M. Estabilidade de taludes Naturais e de Escavação. São Paulo: Edgard Blucher, 2a ed., 194p., 1984. GUZZETTI, F.; CARRARA, A.; CARDINALI, M.; REICHENBACH, P. Landslide hazard evaluation: a review of current techniques and their application in a multi-scale study, Central Italy. Geomorphology vol.31 n. 1-4 p.181-216, 1999.

HUTCHINSON, J.N. General Report: Morphological and Geotechnical Parameters of Landslides in Relation to Geology and Hydrogeology. In: 5th International Symposium on Landslides, Lausanne, vol.1, p.3-35., 1988.

IPT - Instituto de Pesquisas Tecnológicas. Manual de Ocupação de Encostas. Cunha, M.A. (Coord.). Publicação IPT n.1831, 216p., 1991.

MORGAN, R.P.C. Soil Erosion and Conservation. AddisonWoesley, $2^{\mathrm{a}}$ ed., 1996.

PRADINI, F.L.; GUIDICINI, G.; BOTURA, J.A.; PONÇANO, W.L.; SANTOS, A.R. Atuação da cobertura vegetal na estabilidade de encostas: uma resenha crítica. São Paulo: IPT - Divisão de Minas e Geologia aplicada. Publicação 1074, 1976.

RICKSON, R.J. Simulated vegetation and geotextiles. In: Slope stabilization and erosion control a bioengineering approach/ Morgan, R.P.C. e Rickson, R.J.(Eds.). London: E\&FN Spon, p.95-125, 1995.

ROISENBERG, A. e VIERO, A.P. O vulcanismo magmático da Bacia do Paraná no Rio Grande do Sul. In: Geologia do Rio Grande do Sul/De Ros, L.F. e Holz. M. (organizadores). Porto Alegre: CIGO/UFRGS, p.355-374, 2000.

SAATY, R.W. The analytic hierarchy process -- what it is and how it is used. Mathematical Modeling 9, p.161-176, 1987.

SELBY, M.J. Hillslope Materials and Process. New York: Oxford University Press, 451p., 1993.

SHARPE, C.F.S. Landslides and related phenomena. New York: Columbia University press, 1938.

SOETERS, R. e VAN WESTEN, C.J. Slope instability recognition, analysis, and zonation. In: Landslides Investigation and Mitigation/TURNER, A.K. e SCHUSTER, R.L. Special Report 247, Transportation Research Board, National research Council, Washington D.C., p.129-177, 1996.

SANTOS, A.R. A grande barreira da Serra do Mar: da trilha dos Tupiniquins à Rodovia dos Imigrantes. São Paulo: O Nome da Rosa, 122p., 2004.

VANACÔR, R. N. Sensoriamento Remoto e Geoprocessamento aplicados ao mapeamento das áreas susceptíveis a movimentos de massa na região nordeste do Estado do Rio Grande do Sul. Dissertação de Mestrado. Programa de Pós Graduação em Sensoriamento Remoto. Porto Alegre: CEPSRM/UFRGS. 129 p., 2006.

VARNES, D.J. Slope movement and types and process. In: Landslides: Analysis and control/R.L. Schuster e R.J. Krizek (Eds.). Transportation Research Board Special Report 176. National Academy of Sciences, Washington DC, p.11-33, 1978.

VARNES, D.J. Landslides Hazard Zonation - a review of the principles and practice. Paris: UNESCO, 63p., 1984. 